\title{
COCHLEAR IMPLANTS AND TELEPHONE USE: PERFORMANCE ASSESSMENT IN ADULT PATIENTS
}

\author{
Jorge Humberto Martins, Marisa C. Alves, Daniela C. Ramos, Helena M. F. Alves, \\ Jorge Quadros, Carlos A. R. Ribeiro, António D. Paiva
}

ENT Department, Centro Hospitalar Universitário de Coimbra, Coimbra, Portugal

Corresponding author: Jorge Humberto Ferreira Martins, Centro Hospitalar de Coimbra, Quinta dos Vales

- S. Martinho do Bispo, Apartado 7005, 3041-853 Coimbra, Portugal,e-mail: aud.jorgehumberto@gmail.com

\begin{abstract}
Background: Using the telephone for everyday communication and social interaction allows the profoundly deaf patient who uses a cochlear implant to increase their independence and self-esteem. Being able to use the telephone presupposes the ability to perceive speech without the aid of lipreading or any other visual cue.

Objective: This paper aims to evaluate speech perception performance through the telephone in adult users of cochlear implants.

Study sample: 200 adult patients who had used a cochlear implant for a minimum of 1 year were evaluated with speech perception tests (words and sentences) in free-field and through the telephone. They were divided into two groups: group I, composed of individuals who used the telephone in everyday life, and group II, individuals who did not use it.

Results: The results showed statistically significant differences in free-field tonal and vocal thresholds between both groups, with better performance from group I. When the speech perception test results in free-field and through the telephone were compared, for both groups the performance was better in free-field.
\end{abstract}

Conclusions: The results showed a statistically significant difference between the two groups, with better performance from group I in all tests.

Keywords: cochlear implant • profound hearing impairment $\bullet$ telephone use

\section{IMPLANTES COCLEARES Y EL USO DE TELÉFONO: EVALUACIÓN DE RESULTADOS EN PACIENTES ADULTOS}

\section{Resumen}

Introducción: El uso de teléfono en la comunicación diaria por los pacientes con pérdida auditiva profunda, a los que se había insertado el implante coclear, y la interacción social de dichos pacientes, permite aumentar su independencia y su autoestima. El uso de teléfono es una habilidad, en la que, por definición, se entiende el habla sin ayuda de lectura de labios y sin otras señales visuales.

Objetivo: El objetivo del presente estudio ha sido el de evaluar la comprensión del habla por teléfono en usuarios adultos de implantes cocleares.

Materiales: 200 pacientes adultos, usuarios de implantes cocleares durante al menos un año, han sido examinados a través de la prueba de la comprensión de lenguaje (palabras y sentencias) en el campo libre y por teléfono. Han sido divididos en dos grupos: I grupo compuesto de personas que utilizan teléfono en su vida diaria y el II grupo, en el que las personas no utilizaban el teléfono a diario.

Resultados: Los resultados muestran unas diferencias estadísticamente relevantes en los umbrales de la audiometría tonal y verbales, en el campo libre entre ambos grupos; asimismo, los mejores resultados han sido obtenidos en el I grupo. Comparando los resultados de estudios de la comprensión del habla en el campo libre y por teléfono, los resultados en ambos grupos han sido mejores para el campo libre.

Conclusiones: Los resultados han demostrado una diferencia estadísticamente relevante entre ambos grupos, y los resultados mejores para todas las pruebas se han obtenido en el I grupo.

Palabras clave: implante coclear • pérdida auditiva profunda $\bullet$ uso de teléfono 


\section{УЛИТКОВЫЕ ИМПЛАНТАТЫ И ПОЛЬЗОВАНИЕ ТЕЛЕФОНОМ: ОЦЕНКА РЕЗУЛЬТАТОВ У ВЗРОСЛЫХ ПАЦИЕНТОВ}

\section{Изложение}

Введение: Пользование телефоном в ежедневной коммуникации пациентами с глубокой тугоухостью, которым был вживлен улитковый имплантат, а также общественные отношения этих пациентов позволяют повысить их независимость и чувство собственного достоинства. Пользование телефоном является умением, при котором, по идее, речь понимается без помощи чтения по губам или других визуальных сигналов.

Цель: Целью настоящей работы является оценка понимания речи по телефону у взрослых пользователей улитковых имплантатов.

Материал: 200 взрослых пациентов, пользующихся улитковыми имплантатами на протяжении как минимум одного года, были исследованы с помощью теста на понимание речи (слов и предложений) в свободном поле и по телефону. Они были разделены на две группы: группа I состояла из пациентов, пользующихся телефоном в ежедневной жизни, в группе II находились пациенты, которые не пользуются телефоном.

Результаты: Результаты показывают статистически существенную разницу в порогах тональной и словной аудиометрии в свободном поле между двумя группами, вместе с тем лучшие результаты получены в группе I. Сравнивая результаты исследований понимания речи в свободном поле и по телефону, результаты в обеих группах были лучше для свободного поля.

Выводы: Результаты показали статистически существенную разницу между двумя группами, вместе с тем лучшие результаты для всех исследований были получены в группе I.

Ключевые слова: улитковый имплантат • глубокая тугоухость • пользование телефоном

\section{IMPLANTY ŚLIMAKOWE A KORZYSTANIE Z TELEFONU: OCENA WYNIKÓW U DOROSŁYCH PACJENTÓW}

\section{Streszczenie}

Wprowadzenie: Używanie telefonu w codziennej komunikacji przez pacjentów z głębokim niedosłuchem, którym wszczepiono implant ślimakowy, oraz interakcja społeczna tych pacjentów pozwalają na zwiększenie ich niezależności i poczucia własnej wartości. Korzystanie z telefonu jest umiejętnością, w której z założenia mowa rozumiana jest bez pomocy czytania z ust lub innych sygnałów wzrokowych.

Cel: Celem tej pracy jest ocena rozumienia mowy przez telefon u dorosłych użytkowników implantów ślimakowych.

Materiał: 200 dorosłych pacjentów, korzystających z implantów ślimakowych przez minimum rok, zbadano za pomocą testu rozumienia mowy (słów i zdań) w wolnym polu oraz przez telefon. Podzielono ich na dwie grupy: grupę I, składającą się z osób korzystających z telefonu w codziennym życiu, oraz grupę II, w której znalazły się osoby niekorzystające z telefonu.

Wyniki: Wyniki wskazują na statystycznie istotne różnice w progach audiometrii tonalnej i słownej w wolnym polu pomiędzy obiema grupami, przy czym lepsze wyniki uzyskano w grupie I. Porównując wyniki badań rozumienia mowy w wolnym polu i przez telefon, wyniki w obu grupach były lepsze dla wolnego pola.

Wnioski: Wyniki pokazały statystycznie istotną różnicę pomiędzy obiema grupami, przy czym lepsze wyniki dla wszystkich badań uzyskano w grupie I.

Słowa kluczowe: implant ślimakowy • głęboki niedosłuch • korzystanie z telefonu

\section{Background}

The telephone allows immediate communication over a distance, and even now, with other forms of remote communication easily available, it continues to play an important role in daily life. However, patients with severe to profound hearing loss have only a limited ability to use this communication tool, frequently being unable to use it at all [1]. This has a negative impact on their quality of life, either socially, in interaction with family and friends, or in work-related situations, where it can limit on individual's capacity [2]. If one cannot see the speaker and is 
deprived of information about facial expression or body language, as happens with a telephone, this creates even more difficulty. Profoundly deaf adults and children, who depend on seeing the speaker to lipread, have previously had no options for using a standard telephone. However, cochlear implants (CIs) now allow profoundly deaf individuals to have speech perception, and giving them access to the telephone [3].

In 1985, Brown and colleagues reported how CI users could discriminate sentences over the telephone [1]. According to Thomas and colleagues [4], 41 of 55 individuals with severe to profound sensorineural hearing loss had utmost difficulty using the telephone at work. These difficulties relate to the degree and type of hearing loss, the absence of visual information (such as lipreading) to help them understand the message, and to the limitation that telephones convey frequency information only between 300 and $3400 \mathrm{~Hz}[3,4]$, meaning that a part of the frequency spectrum important for speech comprehension is missing.

Adams and colleagues [5] show that many CI patients can use the telephone without the need of assistive devices or relay services. In their study, $42 \%$ of participants used the telephone without other aids. There are several factors that affect an individual's performance with the telephone. One of them is psychological: the apprehension that they will not be able to understand the message correctly, especially if the speaker is unknown [6].

Calvo and colleagues [4] in a study that evaluated 21 patients through a questionnaire, found that although all patients used the telephone, only $66.7 \%$ used a cell phone. The lower percentage of cell phone users may be explained by the fact that some cell phones interfere with the speech processor due to their transmission power. Such interference can be reduced if the cell phone is some distance from the speech processor [4].

Giles [7] found that $81 \%$ of individuals said they felt anxious when using the telephone with an unknown speaker [7], and sometimes only a single negative experience is enough to discourage telephone use for a long time [8]. Given this fact, Ito and colleagues evaluated the possibility of improving the performance of such individuals with commercial assistive listening devices or accessories made available more recently by various cochlear implant manufacturers [6].

Cohen and colleagues [9] found that $23 \%$ of implanted patients used the telephone without any limitation, while $50 \%$ did so with some limitations [9]. Dorman and colleagues evaluated 66 patients fitted with the Ineraid cochlear prosthesis and found that $66 \%$ could answer the telephone [10]. Of the patients who answered the telephone, $49 \%$ indicated that they could identify the gender and/or age of the caller most of the time, $27 \%$ could identify a familiar caller most of the time, and $48 \%$ indicated that they could understand a conversation most of the time if speaking to a familiar speaker about a familiar topic. Understanding dropped rapidly as the speaker and topic became unfamiliar [10].
Anderson and colleagues, in a multicenter research effort covering six countries, evaluated 196 individuals who were unable to use a telephone or a cell phone prior to cochlear implantation [2]. After surgical implantation and rehabilitation, $71 \%$ individuals used the telephone and $54 \%$ the cell phone. In the same study, it was found that time of deafness is an important factor in the performance achieved by the implanted patients, with the results being worse as time of deafness increases [2].

Cray and colleagues specify two factors for increasing speech perception ability over the telephone: one is better technology used in cochlear implants and the other is improved telephone technology [11]. In the same work, 85\% of individuals stated that they could, after 5 months of using the speech processor, use the telephone with strangers, and $30 \%$ said they could use the cell phone [11].

Wieker and Tearney examined assistive listening devices available for telephones and cell phones which are available as a speech processor accessory or from various telecommunication firms [12]. Such equipment is important in noisy situations, although they are not practical if the person is not at home or work.

Martins and colleagues studied the speech perception of 70 adult cochlear implant users both in free field and over the telephone [13]. In this 2010 study, the patients were divided into two groups: group I, 47patients (67\%) who used the telephone, and group II, 23 patients (33\%) who did not. They found no statistically significant differences in free field tonal threshold between the groups. For speech perception in free field, there was a statistically significant difference between the groups, with group I having a better performance. When sentence and word perception results in free field and over the telephone were compared, the performance was better in free-field [13].

The objective of the present study was to compare the performance of adult cochlear implant patients who use the telephone in their everyday life with the performance of those who do not use it. We also wanted to compare their tonal audiometry and speech audiometry, and to compare the performance of both groups on word and sentence perception tests presented in two situations: in free-field (without lip reading) and over the telephone. We find that telephone use among cochlear implant patients has increased compared to previous studies. In this context, we note that highest attained education and post-implant hearing scores are independently correlated to telephone use [14].

\section{Methods}

\section{Design}

The evaluation materials used were a word perception test (100 words frequently used in everyday communication) and a sentences perception test (20 sentences) [14]. The sentences were presented at $65 \mathrm{~dB}$ SPL via loudspeakers in a soundproof room. A GSI-33 audiometer, a PC, and two Panasonic telephones (model KX-TSC8SPW) were used to present the evaluation materials. 
Table 1. Characteristics of patients and their Cls

\begin{tabular}{|c|c|c|c|}
\hline & & Group I & Group II \\
\hline \multirow{2}{*}{ Gender } & Male & $52.1 \%$ & $58.9 \%$ \\
\hline & Female & $47.9 \%$ & $41.1 \%$ \\
\hline \multicolumn{2}{|c|}{ Time of auditory deprivation (years) } & $4.75 \pm 6.48$ & $11.95 \pm 14.77$ \\
\hline \multirow{9}{*}{ Etiology of deafness } & Meningitis & $4 \quad(2.78 \%)$ & $(5.36 \%)$ \\
\hline & Head trauma & $8 \quad(5.56 \%)$ & $3 \quad(5.36 \%)$ \\
\hline & Progressive & $97 \quad(67.36 \%)$ & $37 \quad(66.07 \%)$ \\
\hline & Sudden & $10 \quad(6.94 \%)$ & $2 \quad(3.57 \%)$ \\
\hline & Otosclerosis & $15(10.42 \%)$ & $7 \quad(12.50 \%)$ \\
\hline & Meniere & $1 \quad(0.69 \%)$ & $(3.57 \%)$ \\
\hline & Encephalitis & $1 \quad(0.69 \%)$ & $(0.00 \%)$ \\
\hline & latrogenic & $(2.08 \%)$ & (3.57\%) \\
\hline & Usher syndrome & $5 \quad(3.47 \%)$ & $(0.00 \%)$ \\
\hline \multicolumn{2}{|l|}{ Age at implantation (years) } & $\begin{array}{c}\text { av } 44.64 \pm 14.58 \\
\text { (min } 16 ; \max 83)\end{array}$ & $\begin{array}{l}\text { av } 46.84 \pm 17.44 \\
(\min 16 ; \max 83)\end{array}$ \\
\hline \multirow{2}{*}{ Implanted ear } & Right & $63.2 \%$ & $51.8 \%$ \\
\hline & Left & $36.8 \%$ & $48.2 \%$ \\
\hline \multicolumn{2}{|l|}{ Time of $\mathrm{Cl}$ use (years) } & $\begin{array}{l}\text { av } 6.81 \pm 4.54 \\
(\min 1 ; \max 21)\end{array}$ & $\begin{array}{c}\text { av } 6.67 \pm 5.31 \\
(\min 1 ; \max 27)\end{array}$ \\
\hline \multirow{2}{*}{ Cochlear implant system } & Cochlear & $75.4 \%$ & $62.3 \%$ \\
\hline & MedEl & $24.6 \%$ & $37.7 \%$ \\
\hline \multirow{9}{*}{ Cochlear implant model } & $\mathrm{Cl} 22$ & $4.2 \%$ & $3.8 \%$ \\
\hline & $\mathrm{Cl} 24 \mathrm{M}$ & $7.0 \%$ & $1.9 \%$ \\
\hline & $\mathrm{Cl} 24 \mathrm{~K}$ & $0.7 \%$ & $0.0 \%$ \\
\hline & $\mathrm{Cl} 24$ Contour & $11.6 \%$ & $9.4 \%$ \\
\hline & Cl24 Advance & $9.9 \%$ & $11.3 \%$ \\
\hline & CI24 RE CA & $39.4 \%$ & $34.0 \%$ \\
\hline & $\mathrm{Cl} 512$ & $2.8 \%$ & $1.9 \%$ \\
\hline & Pulsar Ci100 & $2.1 \%$ & $1.9 \%$ \\
\hline & Sonata Ti100 & $22.5 \%$ & $35.8 \%$ \\
\hline
\end{tabular}

The patients were evaluated in free field and through the telephone without using any assistive listening devices, using directly the speech processor's microphones. Results were recorded, organized, and analyzed using the SPSS statistics software version 17 .

\section{Study sample}

Patient selection. We accessed our adult patient database at the ENT Department of Centro Hospitalar de Coimbra to identify all the patients who had at least 1 year of cochlear implant use. All had used hearing aids prior to cochlear implantation. The study evaluated 200 individuals divided into two groups: group I comprised 144 individuals (72\%) who used the telephone in their everyday life, and group II comprised 56 individuals (28\%) who did not use it.

\section{Results}

Table 1 shows the characteristics of the participants, time of auditory deprivation, etiology of deafness, age at implantation, time of CI use, implanted ear, and cochlear implant system and model.

\section{Test results}

All patients were evaluated regarding pure tone and speech audiometry under free field conditions with their cochlear implant. Before statistical analysis, the distribution of the sample was assessed with a one sample Kolmogorov-Smirnov test. Because the sample did not have a normal distribution, a nonparametric test (two independent sample Mann-Whitney U test) was applied. A comparison was made between both groups regarding pure tone thresholds; results are presented in Table 2 and Figure 1.

As shown in Table 2, statistically significant differences between the groups $(p<0.05)$ are obtained at all frequencies (except at $250 \mathrm{~Hz}$ ).

A comparison was also made between both groups regarding speech audiometry thresholds, determined with 
Table 2. Comparison with Mann-Whitney test of the free-field thresholds with $\mathrm{Cl}$ Mann-Whitney Test

\begin{tabular}{lcccccc}
\hline \multicolumn{1}{c}{ Test Statistics* } & cl250f & cl500f & cl1000f & cl2000f & cl4000f \\
\hline Mann-Whitney U & 3509.000 & 3138.000 & 3029.000 & 2960.000 & 3209.000 & 3152.500 \\
\hline Wilcoxon W & 13949.000 & 13578.000 & 13469.000 & 13400.000 & 13649.000 & 13592.500 \\
\hline Z & -1.444 & -2.493 & -2.800 & -2.972 & -2.273 & -2.423 \\
\hline Asymp. Sig. (2-tailed) & .149 & .013 & .005 & .003 & .015 \\
\hline
\end{tabular}

* Grouping Variable: Phone

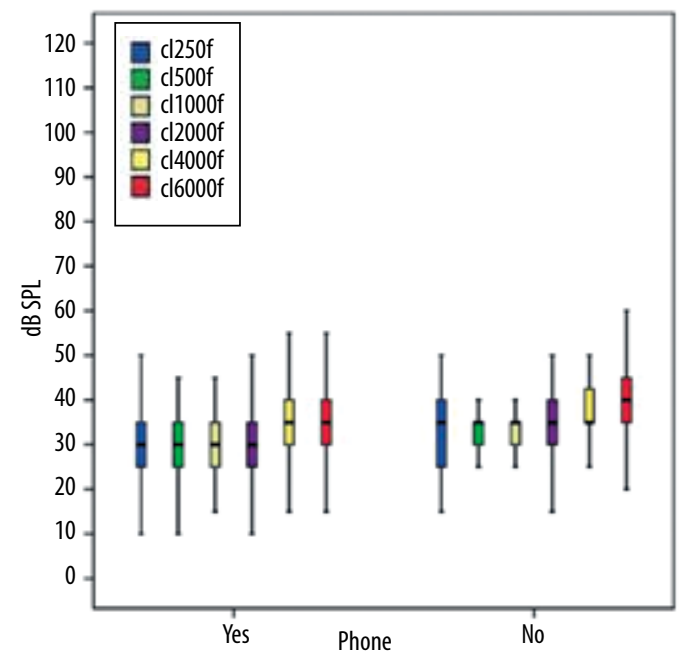

Figure 1. Free field pure tone thresholds in the two groups

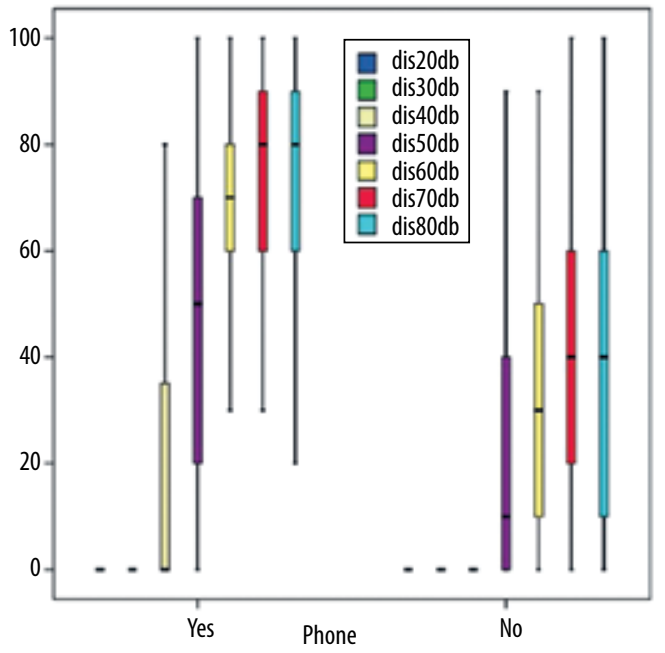

Figure 2. Free field speech audiometry thresholds in the two groups

Table 3. Comparison with Mann-Whitney test of\% discrimination test between the two groups Mann-Whitney Test

\begin{tabular}{lccccccc}
\hline \multicolumn{1}{c}{ Test Statistics* } & dis20db & dis30db & dis40db & dis50db & dis60db & dis70db & dis80db \\
\hline Mann-Whitney U & 3780.000 & 3467.500 & 2611.000 & 1953.500 & 1106.500 & 1043.500 & 1200.000 \\
\hline Wilcoxon W & 5265.000 & 4952.500 & 4096.000 & 3438.500 & 2591.500 & 2528.500 & 2685.000 \\
\hline Z & .000 & -1.925 & -3.793 & -5.274 & -7.684 & -7.877 & -7.411 \\
\hline Asymp. Sig. (2-tailed) & 1.000 & .054 & .000 & .000 & .000 & .000 \\
\hline
\end{tabular}

* Grouping Variable: Phone

dissyllabic lists for adults; results are presented in Table 3 and in Figure 2.

As shown in Table 3, statistically significant differences between both groups in speech audiometry was verified at intensities from 40 to $80 \mathrm{~dB}$ SPL $(p<0.001)$. Figure 2 shows the results obtained by both groups, with higher scores and less dispersion in group I.

A comparison was made between both groups in the four test situations; results are presented in Table 4 and Figure 3 .

A comparison was made between the four test situations, to evaluate the performance in free field and through the telephone; results are presented in Table 4 and Figure 3. The results obtained by group I were always higher and showed lower dispersion, and with statistically significant difference $(p<0.001)$ when compared to the results of group II.

From the analysis of Table 5, we can conclude that the performance obtained in the telephone tests was always inferior, with statistical difference $(p<0.001)$, when compared with free field tests.

\section{Conclusions}

Our results show that telephone communication is possible for an increasing number of patients who use cochlear implants. After evaluation and analysis of the data, we conclude that there is a statistically significant difference 
Table 4. Comparison with Mann-Whitney test in the four evaluations Mann-Whitney Test

\begin{tabular}{|c|c|c|c|c|}
\hline Ranks & Phone & $\mathbf{N}$ & Mean Rank & Sum of Ranks \\
\hline \multirow{3}{*}{ List of sentences (\%) } & Yes & 144 & 121.40 & 17482.00 \\
\hline & No & 56 & 46.75 & 2618.00 \\
\hline & Total & 200 & & \\
\hline \multirow{3}{*}{$\begin{array}{l}\text { List of sentences } \\
\text { - Phone }(\%)\end{array}$} & Yes & 144 & 126.83 & 18263.50 \\
\hline & No & 56 & 32.79 & 1836.50 \\
\hline & Total & 200 & & \\
\hline \multirow{3}{*}{ Test 100 words (\%) } & Yes & 144 & 119.77 & 17246.50 \\
\hline & No & 56 & 50.96 & 2853.50 \\
\hline & Total & 200 & & \\
\hline \multirow{3}{*}{$\begin{array}{l}\text { Test } 100 \text { words } \\
\text { - Phone (\%) }\end{array}$} & Yes & 144 & 124.00 & 17856.00 \\
\hline & No & 56 & 40.07 & 2244.00 \\
\hline & Total & 200 & & \\
\hline Test Statistics* & List of sentences (\%) & $\begin{array}{l}\text { List of sentences } \\
\text { - Phone (\%) }\end{array}$ & Test 100 words (\%) & $\begin{array}{c}\text { Test } 100 \text { words } \\
\text { - Phone (\%) }\end{array}$ \\
\hline Mann-Whitney U & 1022.000 & 240.500 & 1257.500 & 648.000 \\
\hline Wilcoxon W & 2618.000 & 1836.500 & 2853.500 & 2244.000 \\
\hline Z & -8.201 & -10.342 & -7.552 & -9.226 \\
\hline Asymp. Sig. (2-tailed) & .000 & .000 & .000 & .000 \\
\hline
\end{tabular}

* Grouping Variable: Phone

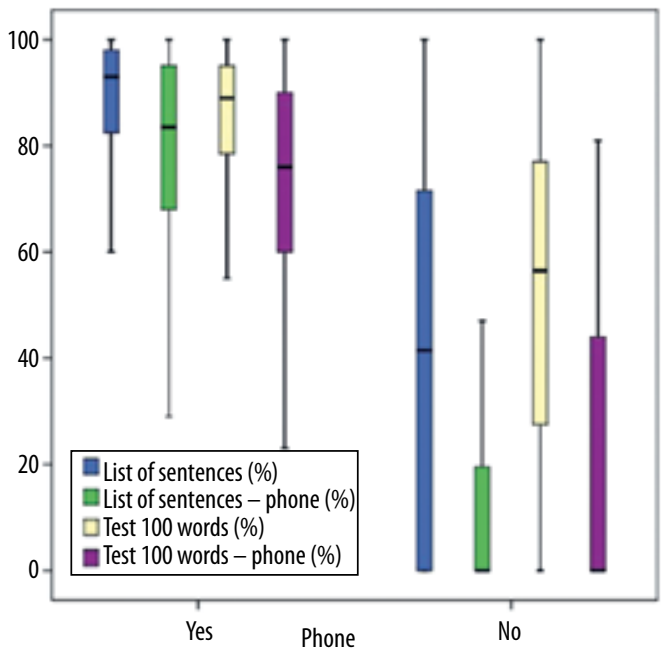

Figure 3. A comparison was made between both groups in the four test situations

between both groups in pure tone threshold and that group I has a better performance in speech audiometry. Group I has a better performance in sentence and word perception tests in both test situations (free field and telephone).
Taking into consideration that the two groups have similar average time of use, the results can be explained by the fact that group II had a longer time of hearing deprivation, as explained by Anderson et al. [2]. In the same work, which had a similar sample to our work, the authors reported that $71 \%$ of implanted individuals used the telephone, a value similar to that found in our sample.

These findings might help motivate patients who do not use the telephone to use available strategies to develop this skill. This work has allowed us to better understand the benefits available to cochlear implant patients in terms of social interaction, benefits which contrast with the difficulties they encountered before auditory rehabilitation with a cochlear implant. The benefits contribute towards development of autonomy, self-esteem, and social and professional integration.

We aim to broaden this work to study all implanted patients at Centro Hospitalar Universitário de Coimbra; we will also evaluate their performance with a cell phone and use questionnaires to assess their own quality of life rating.

Competing Interests: The authors declare that no competing interests exist and that they have fulfilled all legal requirements for the study. 
Table 5. Comparison with two related-samples test - Wilcoxon in the two different test situations Wilcoxon Signed Ranks Test

\begin{tabular}{|c|c|c|c|c|}
\hline Ranks & & $\mathbf{N}$ & Mean Rank & Sum of Ranks \\
\hline \multirow{4}{*}{$\begin{array}{l}\text { List of sentences } \\
\text { - Phone }(\%) \\
\text { - List of sentences (\%) }\end{array}$} & Negative Ranks & 126 & 97.27 & 12256.50 \\
\hline & Positive Ranks & 46 & 56.99 & 2621.50 \\
\hline & Ties & 28 & & \\
\hline & Total & 200 & & \\
\hline \multirow{4}{*}{$\begin{array}{l}\text { Test } 100 \text { words } \\
\text { - Phone (\%) } \\
\text { - Test } 100 \text { words (\%) }\end{array}$} & Negative Ranks & 167 & 95.02 & 15868.00 \\
\hline & Positive Ranks & 14 & 43.07 & 603.00 \\
\hline & Ties & 19 & & \\
\hline & Total & 200 & & \\
\hline Test Statistics ${ }^{\star \star}$ & \multicolumn{2}{|c|}{$\begin{array}{l}\text { List of sentences - Phone (\%) } \\
\text { - List of sentences (\%) }\end{array}$} & \multicolumn{2}{|c|}{$\begin{array}{l}\text { Test } 100 \text { words - Phone (\%) } \\
\text { - Test } 100 \text { words (\%) }\end{array}$} \\
\hline Z & \multicolumn{2}{|c|}{$-7.367^{\star}$} & \multicolumn{2}{|c|}{$-10.815^{\star}$} \\
\hline Asymp. Sig. (2-tailed) & \multicolumn{2}{|c|}{.000} & \multicolumn{2}{|c|}{.000} \\
\hline
\end{tabular}

* Based on positive ranks; ${ }^{\star \star}$ Wilcoxon Signed Ranks Test

\section{References:}

1. Brown AM, Clark GM, Martin RC, Seligman PM. Telephone use by a multi-channel cochlear implant patient: an evaluation using open-set CID sentences. J Laryngol Otol, 1985; 99: 231-8.

2. Anderson I, Baumgartner WD, Böheim K, Nahler C, Arnolder $\mathrm{C}$ et al. Telephone use: what benefit do cochlear implant users receive? Int J Audiol, 2006; 45(8): 446-53.

3. Tait M, Nikolopoulos T, Archbold S, O’Donoghue G. Use of the telephone in prelingually deaf children with a multichannel cochlear implant. Otol Neurotol, 2001; 22: 47-52.

4. Calvo A, Atienza L, Marti M, Carrillo C, Sarriá Lucas MJ et al. El uso del teléfono en pacientes con implante coclear. Rev Logop Foniat Aud, 2004; 24(3): 132-6.

5. Adams JS, Hasenstab MS, Pippin GW, Sismanis A. Telephone use and understanding in patients with cochlear implants, ENT - Ear Nose Throat Journal, 2004; 83(2): 96-103.

6. Ito J, Nakate M, Fijita S. Hearing ability by telephone of patients with cochlear implants. Otolaryngol Head Neck Surg, 1999; 121: 802-4.

7. Giles EC. An outline of telephone training procedures at the Manchester Cochlear Implant Center. In: Hochmair-Desoyer IJ, Hochmair ES (eds.), Advances in Cochlear Implants. Vienna: Manz, 1994; 604-8.

8. Pedley K, Giles E, Hogan A. Adult Cochlear Implant Rehabilitation. London: Whurr, 2005.
9. Cohen N, Waltzman S, Shapiro WH. Telephone speech comprehension with use of the Nucleus cochlear implant. Ann Otol Rhinol Laryngol, 1989; 98: 8-11.

10. Dorman M, Dove H, Parkin J, Zacharchuk S, Dankowski K. Telephone use by patients fitted with the Ineraid cochlear implant. Ear and Hearing, 1991; 12(5): 368-9.

11. Cray J, Allen R, Stuart A, Hudson S, Layman E et al: An investigation of telephone usage among cochlear implant recipients. Am J Audiol, 2004; 13: 200-12.

12. Wieker N, Tearney L. A cochlear implant user's guide to assistive device and telephones. Hearing J, 2004; 57(11): 20-6.

13. Martins JH, Januário J, Alves M, Ramos D, Alves H et al. Comparative study of words and sentences discrimination: free field and through telephone in cochlear implant patients. Rev Portuguesa Otorrino, 2010; 48(4): 181-9.

14. Clinkard D, Shipp D, Friesen L, Stewart S, Ostroff J, Chen J et al. Telephone use and the factors influencing it among cochlear implant patients. Cochlear Implants International, 2001; 12 (3): 140-6.

15. Martins JH, Januário J, Alves M, Ramos D, Alves H et al. Validation list of monosyllables, numbers and sentences for speech audiometry for adults. Clin Inv Otorrinolaryngologia, 2009; 3(1): 54-59. 